IJAMSR 2 (2) www.ijamsr.com CrossRef: https://doi.org/10.31426/ijamsr.2019.2.2.1218

\title{
A STUDY ON EMOTIONAL INTELLIGENCE AND ACADEMIC ACHIEVEMENT OF TRIBAL AND NON TRIBAL SECONDARY SCHOOL STUDENTS OF DISTRICT KULGAM
}

\section{BILAL AHMAD BHAT}

Ph.D Research Scholar, School of Education and Behavioral Sciences, University of Kashmir, Kashmir India

Email : bhatbilal.scholar@kashmiruniversity.net

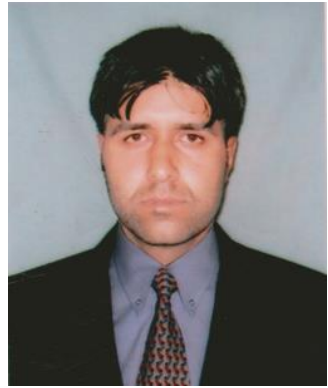

BILAL AHMAD BHAT

\section{Keywords: $\quad$ Emotional} Intelligence, Academic Achievement, Tribal and Non Tribal

\begin{abstract}
A B S T RA C T
Emotional intelligence (EI) refers to the ability to perceive, control and evaluate emotions. The objective of this research is to study, Emotional Intelligence and Academic Achievement of Tribal and Non-Tribal secondary students of district Kulgam. For the present study, the researcher used the Emotional Intelligence scale by Ankool Hyde et al (2001) and it was administered to the sample subjects. Academic achievement was assessed on the basis of the marks obtained by the students in their 8th class examination. The significant difference between the means of each pair of group was computed using Standard Deviation, " $t$ " test, Mean and Pearson's Coefficient Correlation. The findings are established and tabulated from the analyzed data. The finding shows that there is no significant difference between emotional intelligence and academic achievement of tribal and non-tribal high school students.
\end{abstract}

Citation: Bilal Ahmad Bhat, (2019). A Study On Emotional Intelligence And Academic Achievement Of Tribal And Non Tribal Secondary School Students Of District Kulgam: International Journal of Advanced Multidisciplinary Scientific Research (IJAMSR ) ISSN:2581-4281, 2 (2), February, 2019, \# Art.1218, pp 83-87 


\section{International Journal of Advanced Multidisciplinary Scientific Research (IJAMSR) ISSN:2581-4281}

\section{Introduction}

Emotional intelligence (EI) is also about the ability to reason and problem-solve, based on the emotions we experience. Goleman has rightly defined that "Emotional intelligence is the ability to perceive emotions; to access and generate emotions so as to assist thought; to understand emotions and emotional knowledge; and to reflectively regulate emotions so as to promote emotional and intellectual growth." The first use of the term "emotional intelligence" is usually attributed to Wayne Payne's doctoral thesis, A Study of Emotion: Developing Emotional Intelligence (1985). Salovey and Mayer (1990) have been the leading researchers on emotional intelligence. In their influential article "Emotional Intelligence," they defined emotional intelligence as, "the subset of social intelligence that involves the ability to monitor one's own and others' feelings and emotions, to discriminate among them and to use this information to guide one's thinking and actions". There are two different kinds of intelligence: the rational one and the emotional one. Our performance is determined not only by IQ (Intellectual quotient), but mainly by emotional intelligence, sometimes, also named of emotional quotient (EQ). In fact, the cognitive side cannot give its best without the emotional intelligence. When both interact well, the emotional intelligence increases, increasing also the intellectual capacity. Emotional intelligence can be defined as the ability to monitor one's own and other people's emotions, to discriminate between different emotions and label them appropriately and to use emotional information to guide thinking and behavior.

\section{Significance of the Study}

India is the home to a large number of tribal people, who are still untouched by the lifestyle of the modern world. With more than 84.4 million, India has the largest population of the tribal people in the world. Tribal's constitute $8.61 \%$ of the total population of the country, numbering 104.28 million (2011 Census) and cover about $15 \%$ of the country's area. In the modern world, education is getting widened and there is a cut-throat competition among students to excel. Students feel difficult to control their emotions in order to face various situations in school life. It is imperative to manage the stress and strain to keep pace with the demands of the world. The way of managing emotions is crucial for better performance. Even after they got into the field, they desire, their academic achievement is not at all adequate. Success in academics can be 


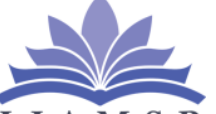

International Journal of Advanced Multidisciplinary Scientific Research (IJAMSR) ISSN:2581-4281

predicted more by emotional measures. Parent and teachers focus always on academic performance through nurturing intelligent and they give tiniest importance to their emotions. Emotions of a student can affect him in many ways. Intelligence may help students in acquiring subject knowledge, but only emotional intelligence can enrich their learning proficiency and make them efficient as well as achievers. Hence, the present study has been undertaken to study the emotional intelligence and academic achievement of high school students. Research shows that a very few studies have been conducted on emotional intelligence in relation to tribal and non-tribal students, but no such study has been conducted in district Kulgam of Kashmir valley; therefore investigator makes a humble attempt in this direction.

\section{A statement of the Problem:}

The problem for the proposed study is stated as below:

"A study on Emotional Intelligence and Academic Achievement of Tribal and Non Tribal Secondary school Students of District Kulgam"

\section{Operational Definitions}

\section{Emotional Intelligence}

Salovey and Mayer (1997) define Emotional Intelligence as "the ability to perceive and express emotion, assimilate emotion in thought, understand and reason with emotion, and regulate emotion in the self and others" (p. 10). According to Goleman (1995) emotional intelligence consists of five components: Knowing our emotions (self-awareness), managing them, motivating ourselves, recognizing emotions in others (empathy), and handling relationships.

\section{Academic Achievement}

Academic achievement is defined as the level of actual accomplishment or proficiency one has achieved in an academic area, as opposed to one's potential in the educational goals measured by examinations. Academic achievement is defined by Crow and Crow (1969) as the extent to which a learner is profiting from instructions in a given area of learning, i.e., achievement is reflected by the extent to which skill and knowledge has been imparted to him. 
International Journal of Advanced Multidisciplinary Scientific Research (IJAMSR) ISSN:2581-4281 Volume 2, Issue 2, February, 2019

IJAMSR 2 (2) www.ijamsr.com CrossRef: https://doi.org/10.31426/ijamsr.2019.2.2.1218

International Journal of

I J A M S R

\section{Advanced Multidisciplinary Scientific Research (IJAMSR) ISSN:2581-4281}

\section{High School Students}

High school students are the students who are studying in classes IX and $\mathrm{X}$ standards. Kulgam District is a district in Jammu and Kashmir State of India.

\section{Objectives Of The Study:}

- To compare Tribal and Non-Tribal secondary students on emotional intelligence.

- To compare Tribal and Non-Tribal secondary students on academic achievement.

- To study, Emotional Intelligence and Academic Achievement of Tribal and Non-Tribal secondary school students.

- To find the relationship between emotional intelligence and academic achievement of tribal students.

- To find the relationship between emotional intelligence and academic achievement of Non-tribal students

\section{Null Hypotheses}

- There is no significant difference between emotional intelligence of tribal and Non-tribal students (composite).

- There is no significant difference between emotional intelligence of tribal and non-tribal students (Factor wise).

- There is no significant difference between emotional intelligence of tribal and non-tribal students (Gender).

- There is no correlation between emotional intelligence and academic achievement of tribal students.

- There is no correlation between emotional intelligence and academic achievement of non-tribal students.

\section{Delimitation Of The Problem}

The study was delimited to district Kulgam.

\section{Methods and Procedure}

Survey method is adopted for the study. Data is collected from a sample of 120 students studying in IX and $\mathrm{X}$ standard from high schools in Kulgam district that were selected randomly. 
For the present study, the investigator used Emotional Intelligence scale by Ankool Hyde et al (2001) and it was administered to the sample subjects. The Emotional Intelligence Inventory has been designed for use with English and overall marks knowing 16 to 18 years age of high school students for the measurement of their emotional intelligence in respect of 10 dimensions of emotional intelligence namely. Self- awareness, Empathy, Self-motivation, Emotional Stability, Managing Relations, Integrity, SelfDevelopment Value Orientation, Commitment, Altruistic Behavior. It has 34 items, to be answered using 5-point Likert Scale as strongly agrees / agree / uncertain/disagree / strongly disagree. The Academic achievement of the students was assessed by the marks which were obtained by the students in their $8^{\text {th }}$ class examination. The investigator himself administered the test in the selected schools after giving proper instructions. SPSS program was used for analysis of the collected data. For analysis of data and interpretation of results, Mean, Standard deviation, t-test, and Pearson's Coefficient Correlation techniques were used.

\section{TABLE 1:}

Progress of scheduled tribes of India over the years on the literacy front.

\begin{tabular}{|c|c|c|c|c|c|}
\hline Year & |1961|| & || 1971 & |1981 & $|1991|$ & 2001 \\
\hline $\begin{array}{l}\text { Total literate } \\
\text { population }\end{array}$ & $\begin{array}{l}24 \\
\%\end{array}$ & $\begin{array}{c}29.4 \\
\%\end{array}$ & $\begin{array}{c}36.2 \\
\%\end{array}$ & $\mid$\begin{tabular}{c||}
52.2 \\
$\%$
\end{tabular} & $64.84 \%$ \\
\hline $\begin{array}{l}\text { Scheduled } \\
\text { Tribes (STs) } \\
\text { population }\end{array}$ & $\begin{array}{l}8.5 \\
\%\end{array}$ & 11.3 & $\begin{array}{c}16.3 \\
\%\end{array}$ & \begin{tabular}{|c||}
29.6 \\
$\%$
\end{tabular} & $47.10 \%$ \\
\hline $\begin{array}{l}\text { Total female } \\
\text { population }\end{array}$ & $\begin{array}{c}12.9 \\
\%\end{array}$ & $\begin{array}{c}18.6 \\
\%\end{array}$ & $\begin{array}{c}29.8 \\
\%\end{array}$ & $\mid$\begin{tabular}{c||}
39.3 \\
$\%$
\end{tabular} & $53.67 \%$ \\
\hline \begin{tabular}{|l} 
Total \\
Scheduled \\
Tribes (STs) \\
female \\
population
\end{tabular} & $\begin{array}{l}3.2 \\
\%\end{array}$ & $4.8 \%$ & $\begin{array}{c}8.0 \\
\%\end{array}$ & $\mid \begin{array}{c}18.2 \\
\%\end{array}$ & $34.76 \%$ \\
\hline
\end{tabular}

Table 2

Means, standard deviations, and t-value showing differences in scores between Tribal and Non Tribal on Emotional intelligence scale (composite)

\begin{tabular}{|l|l|l|l|l|l|}
\hline Category & N & Mean & S.D & value & Significance \\
\hline Tribal & 60 & 148.39 & 8.30 & & \\
\hline $\begin{array}{l}\text { Non } \\
\text { Tribal }\end{array}$ & 60 & 142.83 & 9.13 & & \\
\hline
\end{tabular}

Note: N.S. =Not Significant 
In the perusal of results from table 2 it can be said that the Tribal and Non Tribal students do not differ significantly on their emotional intelligence (composite scores) as the $\mathrm{t}$ value 1.21 is lower than table ' $t$ ' value at 0.05 levels. Therefore, no decisive decision can be drawn from the results.

Therefore the null hypothesis, "There is no significant difference between the emotional intelligence of Tribal and Non Tribal students". (Composite Score), stands accepted.

\section{Table 3}

Means, standard deviations, and t-value showing differences in scores between Tribal and Non Tribal on Emotional intelligence scale (Factor wise)

\begin{tabular}{|c|c|c|c|c|c|}
\hline & $\mathbf{n}$ & $\begin{array}{c}\text { Mea } \\
\text { n }\end{array}$ & $\begin{array}{l}\text { S. } \\
\text { D }\end{array}$ & $\begin{array}{c}\text { t- } \\
\text { valu } \\
\text { e }\end{array}$ & $\begin{array}{c}\text { Significa } \\
\text { nce }\end{array}$ \\
\hline $\begin{array}{l}\text { Self- } \\
\text { awareness(A) } \\
\text { Tribal } \\
\text { Non Tribal }\end{array}$ & $\begin{array}{l}6 \\
0 \\
6 \\
0\end{array}$ & $\begin{array}{r}15.3 \\
8 \\
17.3 \\
8\end{array}$ & $\begin{array}{r}3.0 \\
8 \\
2.0 \\
1\end{array}$ & 3.86 & $* *$ \\
\hline $\begin{array}{l}\text { Empathy(B) } \\
\text { Tribal } \\
\text { Non Tribal }\end{array}$ & $\begin{array}{l}6 \\
0 \\
6 \\
0\end{array}$ & $\begin{array}{r}18.4 \\
8 \\
17.1 \\
2\end{array}$ & $\begin{array}{r}2.8 \\
4 \\
2.9 \\
9\end{array}$ & 1.33 & N.S \\
\hline $\begin{array}{l}\text { Self- } \\
\text { motivation }(\mathrm{C} \\
\text { Tribal } \\
\text { Trib }\end{array}$ & $\begin{array}{l}6 \\
0\end{array}$ & $\begin{array}{r}22.9 \\
8\end{array}$ & $\begin{array}{r}3.6 \\
6\end{array}$ & 0.02 & N.S \\
\hline
\end{tabular}

\begin{tabular}{|c|c|c|c|c|c|}
\hline Non Tribal & $\begin{array}{l}6 \\
0\end{array}$ & $\begin{array}{r}23.1 \\
8\end{array}$ & $\begin{array}{r}2.7 \\
8\end{array}$ & & \\
\hline $\begin{array}{l}\text { Emotional } \\
\text { Stability(D) } \\
\text { Tribal } \\
\text { Non Tribal }\end{array}$ & $\begin{array}{l}6 \\
0 \\
6 \\
0\end{array}$ & $\begin{array}{r}15.0 \\
3 \\
16.0 \\
7\end{array}$ & $\begin{array}{r}2.7 \\
0 \\
2.5 \\
6\end{array}$ & 1.98 & $*$ \\
\hline $\begin{array}{l}\text { Managing } \\
\text { Relations(E) } \\
\text { Tribal } \\
\text { Non Tribal }\end{array}$ & $\begin{array}{l}6 \\
0 \\
6 \\
0\end{array}$ & $\begin{array}{r}17.1 \\
2 \\
15.9 \\
0\end{array}$ & $\begin{array}{r}2.4 \\
0 \\
2.2 \\
3\end{array}$ & 2.32 & $* *$ \\
\hline $\begin{array}{l}\text { INTEGRITY } \\
(\mathrm{F}) \\
\text { Tribal } \\
\text { Non Tribal }\end{array}$ & $\begin{array}{l}6 \\
0 \\
6 \\
0\end{array}$ & $\begin{array}{r}16.0 \\
8 \\
12.2 \\
3\end{array}$ & $\begin{array}{r}5.3 \\
4 \\
1.6 \\
4\end{array}$ & 0.33 & N.S \\
\hline $\begin{array}{l}\text { Self- } \\
\text { Development } \\
\text { (G) } \\
\text { Tribal } \\
\text { Non Tribal }\end{array}$ & $\begin{array}{l}6 \\
0 \\
6 \\
0\end{array}$ & $\begin{array}{l}7.80 \\
7.97\end{array}$ & $\begin{array}{r}1.6 \\
8 \\
1.1 \\
9\end{array}$ & 0.33 & N.S \\
\hline $\begin{array}{l}\text { Value } \\
\text { Orientation( } \\
\mathrm{H}) \\
\text { Tribal } \\
\text { Non Tribal }\end{array}$ & $\begin{array}{l}6 \\
0 \\
6 \\
0\end{array}$ & $\begin{array}{l}8.15 \\
7.08\end{array}$ & $\begin{array}{r}1.1 \\
0 \\
1.6 \\
5\end{array}$ & 1.77 & $*$ \\
\hline $\begin{array}{l}\text { Commitment } \\
\text { ( I) } \\
\text { Tribal } \\
\text { Non Tribal }\end{array}$ & $\begin{array}{l}6 \\
0 \\
6 \\
0\end{array}$ & $\begin{array}{l}8.35 \\
7.03\end{array}$ & $\begin{array}{r}1.1 \\
5 \\
1.6 \\
9\end{array}$ & 2.37 & $* *$ \\
\hline $\begin{array}{l}\text { Altruistic } \\
\text { Behaviour }(\mathrm{J}) \\
\text { Tribal } \\
\text { Non Tribal }\end{array}$ & $\begin{array}{l}6 \\
0 \\
6 \\
0\end{array}$ & $\begin{array}{l}7.83 \\
8.07\end{array}$ & $\begin{array}{r}1.6 \\
1 \\
1.1 \\
3\end{array}$ & 0.30 & N.S \\
\hline
\end{tabular}

\section{Note:}

$* *=$ Significant at 0.01 level $*=$ Significant at 0.05 level 


\section{N.S. $=$ Not Significant}

Results from the above table 3 reveals that the Tribal students do not differ significantly from the Non Tribal students on five out of ten dimensions of emotional intelligence viz: Empathy, Self-motivation, Integrity, SelfDevelopment and Altruistic behavior as all the $\mathrm{t}$-values are far below the table $\mathrm{t}$-value at 0.05 level, therefore no decisive decision can be taken about these factors.

The results from the table 3 make it clear that the two groups differ significantly on the factor A (self awareness) of emotional intelligence. The mean score of Tribal students (15.38) is lesser than that of Non Tribal students (17.38) indicating that Non-Tribal students are more self aware than Tribal students. The results seem to be justified on the grounds that the backwardness of the Tribal areas results in the lack of self awareness of the child. They seem to be less exposed to the modern technology and facilities. Thus are mostly unaware about their virtues and qualities.

The results from the table 3 also reveal that the two groups differ significantly on the factor D (Emotional stability) of Emotional intelligence. The obtained ' $t$ ' value is 1.98 which is significant at 0.05 level The mean score of the Tribal students (15.03) is less than the mean score of the Non Tribal students (16.07) on the dimension of emotional stability indicating thereby that Non Tribal students are emotionally more stable than Tribal students at secondary level. The results seem justified on the grounds that the sample was taken from government secondary schools of district Kulgam where most of the students where Non Tribal students. Being in minority itself means a psychological disturbance in terms of adjustment and stability. On the other hand the Non Tribal students were having no such problem because they were among their own people, thus keeping them emotionally stable. Possibly the extraneous variables as pointed above might influence their emotional stability.

The results of table- 3 also make it clear that there is a significant difference between the Tribal and Non Tribal students of the factor E (managing relations) of emotional intelligence. The mean score of tribal students (17.12) is more than that of non tribal students (15.90) thereby indicating that the tribe is better at managing relations than Non Tribal students at secondary level. The results seem to be justified on the grounds that tribal societies are more primitive and thus having more solidarity 
IJAMSR 2 (2) www.ijamsr.com CrossRef: https://doi.org/10.31426/ijamsr.2019.2.2.1218

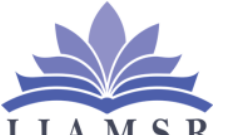

\section{International Journal of} Advanced Multidisciplinary Scientific Research (IJAMSR) ISSN:2581-4281

than non tribal people. This cohesiveness comes by cohesive relations thereby teaching the young ones of the society, how to manage relations with others in order to keep this solidarity ongoing within a community.

The results of table-3 also reveal that there is a significant difference between the Tribal and Non Tribal students on the factor $\mathrm{H}$ (value orientation) of emotional intelligence. The results depict that the mean score of the Tribal students (8.15) is greater than the mean score of the Non Tribal students (7.08) on value orientation. The obtained' value is 1.77 which is significant at 0.05 level. The table, thus shows that Tribal and Non Tribal students differ significantly so far as their value orientation is concerned, indicating thereby that Tribal students are mostly more value oriented than Non Tribal students at secondary school level. The results seem to be defended on the basis that the Tribal children are grown up in joint families under the parental and grand- parental guidance were a greater thrust is on the development of positive values of life and the values are also imbibed from the cohesive congenial atmosphere of Tribal social life, this seem to make them more value oriented. On the other hand, the Non Tribal children are grown up mostly in nuclear

families were most of their family members are working and the children receive very little time and attention of their parents and also the social environment of Non Tribal areas is such that there is almost no social interaction between the society members. Moreover the materialistic attitude of the Non Tribal people seems to make them less value oriented.

The results of table- 3 also make it clear that there is a significant difference between the Tribal and Non Tribal students on the factor I (Commitment) of emotional intelligence. The results depict that the mean score of the Tribal students (8.35) is greater than the mean score of the Non Tribal students (7.03) on Commitment. The obtained ' $t$ ' value is 2.37 which is significant at 0.01 level. The table, thus shows that Tribal and Non Tribal students differ significantly so far as their Commitment is concerned, indicating thereby that Tribal students are mostly more Committed than Non Tribal students.

\section{Table 4:}

A table showing mean Academic
achievement scores of students (Tribal / Non
Tribal)


International Journal of Advanced Multidisciplinary Scientific Research (IJAMSR) ISSN:2581-4281 Volume 2, Issue 2, February, 2019

IJAMSR 2 (2) www.ijamsr.com CrossRef: https://doi.org/10.31426/ijamsr.2019.2.2.1218

International Journal of

I J A M S R

Advanced Multidisciplinary Scientific Research (IJAMSR) ISSN:2581-4281

\begin{tabular}{|l|l|l|l|}
\hline Category & Gender & N & \multicolumn{1}{c|}{ Mean } \\
\hline \multirow{2}{*}{ Tribal } & Boys & 30 & 368.67 \\
\cline { 2 - 4 } & Girls & 30 & 424.90 \\
\hline $\begin{array}{l}\text { Non- } \\
\text { Tribal }\end{array}$ & Boys & 30 & 432.37 \\
\cline { 2 - 4 } & Girls & 30 & 427.00 \\
\hline
\end{tabular}

Table 5

Coefficient of correlation between emotional intelligence and academic achievement on total composite score of tribal students and non-tribal students.

\begin{tabular}{|l|l|l|}
\hline Category & $\mathrm{N}$ & $\begin{array}{l}\text { Correlation of } \\
\text { emotional } \\
\text { intelligence } \\
\text { with academic } \\
\text { achievement. }\end{array}$ \\
\hline Tribal & 60 & +0.45 \\
\hline Non-Tribal & 60 & +0.13 \\
\hline
\end{tabular}

The results from table 4 depict that the mean score of the Tribal boys (369) is lower than the mean score of Tribal girls (425), Non-tribal boys (432) and Non Tribal girls (427) on academic achievement.

The results from table 4 also depict that the mean score of the Tribal boys (369) is lower than the mean score of the Non Tribal boys (432) and Non Tribal girls (425) on academic achievement. In perusal of the results it can be also be said that the overall academic achievement of the tribal students is lower than that of the Non Tribal students.

Thus the null hypothesis, "There is no significant difference between the emotional intelligence of Tribal and Non Tribal students. (Factor Wise)," stands partially rejected.

The results of Table 5 signify that there is a positive correlation between the emotional intelligence and academic achievement of students either tribal as well as non tribal students. The results thus confer that if the emotional intelligence of a student (Tribal or Non Tribal) is higher he may achieve more successful academically and vice versa.

Thus the null hypothesis "there is no correlation between the emotional intelligence and academic achievement of tribal students" stands rejected.

And also the null hypothesis "there is no correlation between the emotional intelligence and academic achievement of non tribal students" stands rejected. 
International Journal of Advanced Multidisciplinary Scientific Research (IJAMSR) ISSN:2581-4281 Volume 2, Issue 2, February, 2019

IJAMSR 2 (2) www.ijamsr.com CrossRef: https://doi.org/10.31426/ijamsr.2019.2.2.1218

\section{International Journal of Advanced Multidisciplinary Scientific Research (IJAMSR) ISSN:2581-4281}

\section{FIGURE 1}

Means and standard deviations showing differences in scores between Tribal and Non Tribal on Emotional intelligence scale (composite).

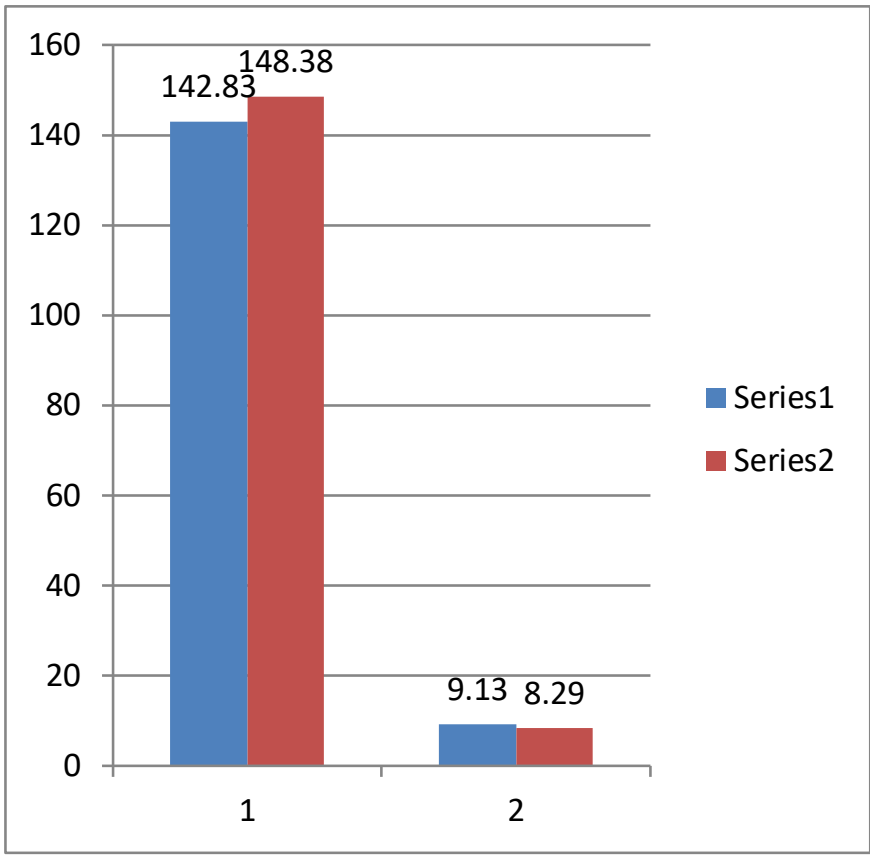

FIGURE 2

Means and standard deviations differences in scores between Tribal and Non Tribal on Emotional intelligence scale (Factor wise)

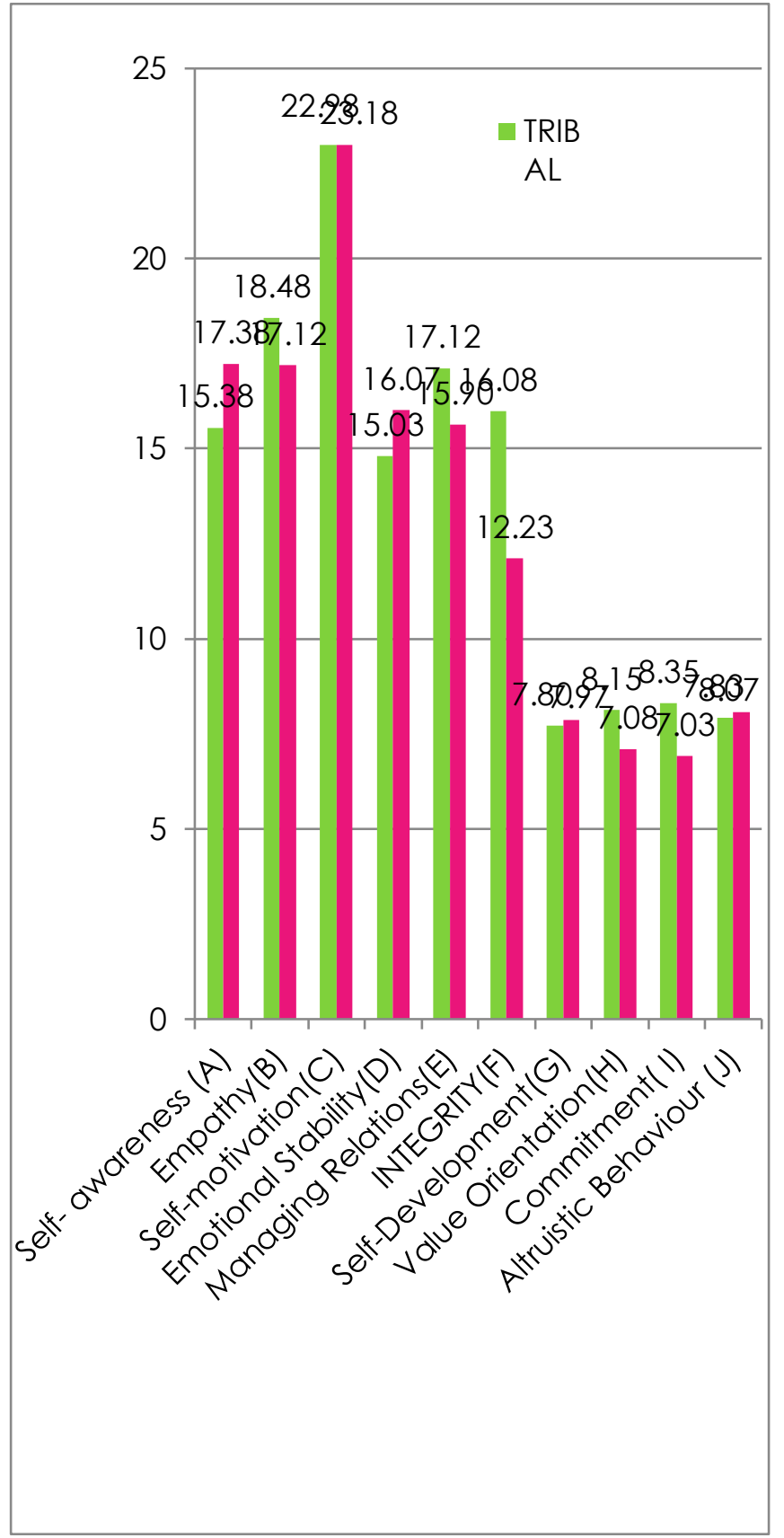


International Journal of Advanced Multidisciplinary Scientific Research (IJAMSR) ISSN:2581-4281 Volume 2, Issue 2, February, 2019

IJAMSR 2 (2) www.ijamsr.com CrossRef: https://doi.org/10.31426/ijamsr.2019.2.2.1218

\section{International Journal of Advanced Multidisciplinary Scientific Research (IJAMSR) ISSN:2581-4281}

\section{FIGURE 3}

\section{Graph showing mean Academic} achievement scores of students (Tribal / Non Tribal)

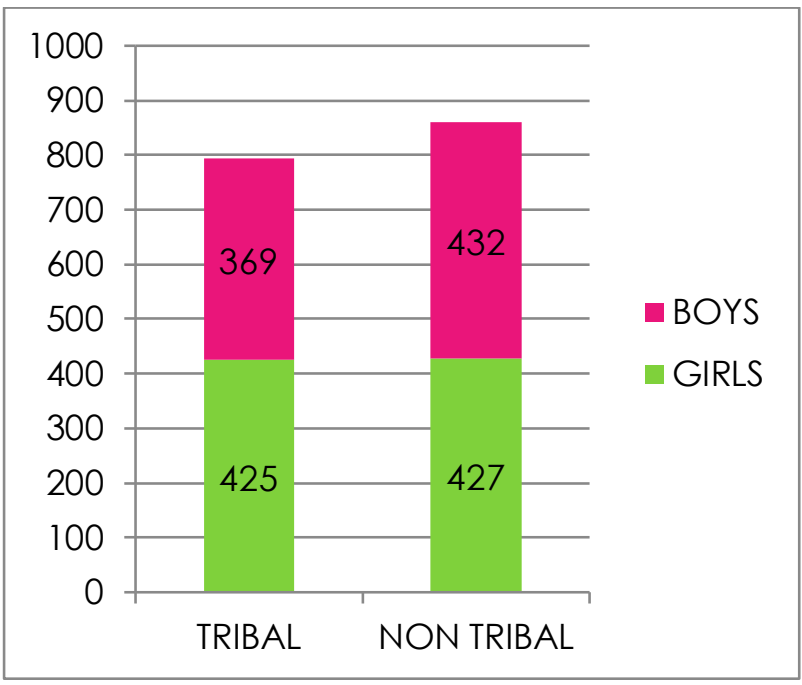

\section{Findings}

1. "There is no significant difference found between the emotional intelligence of Tribal and Non Tribal students".

2. There is no significant difference found between the emotional intelligence of Tribal and Non Tribal students.

3. There is no correlation found between the emotional intelligence and academic achievement of tribal students.
4. There is no correlation found between the emotional intelligence and academic achievement of non tribal students.

5. It was found that the Tribal students do not differ significantly from the Non Tribal students on five out of the ten dimensions of emotional intelligence via: Empathy, Self-motivation, Integrity, and SelfDevelopment and Altruistic behavior.

6. It was found that the two groups differ significantly on the factor A (self awareness) of emotional intelligence.

7. The study makes it clear that the two groups differ significantly on the factor D (Emotional stability) of Emotional intelligence.

8. The study also reveals that there is a significant difference between the Tribal and Non Tribal students of the factor $\mathrm{E}$ (managing relations) of emotional intelligence.

9. The study also discloses that there is a significant difference between the Tribal and Non Tribal students on the factor $\mathrm{H}$ (value orientation) of emotional intelligence. 
IJAMSR 2 (2) www.ijamsr.com CrossRef: https://doi.org/10.31426/ijamsr.2019.2.2.1218

10. The study makes it evident that there is a significant difference between the Tribal and Non Tribal students on the factor I (Commitment) of emotional intelligence.

\section{Inferential Suggestions}

- The Tribal students, when admitted to the institutions, should be encouraged by the institutions to sensitize them about the problems they may face as there is a vast difference between being among their own people and in being among the people that are non tribal, so that they can develop a positive outlook towards these institutions and try to develop problem focused coping strategies to deal with the day to day problems in the institution.

- The senior students in institutions should be sensitized about the ill effects of ragging on newcomers, so that these new comers (Tribal students) will feel at ease which may lessen their emotional problems.
- Proper facilities should be created in the institutions so that the students will not find a large gap between the facilities in these institutions and the home.

- Hostel facilities should be created for all Tribal students, so that they may not have to face problems on account of residing on accommodation.

- All students should be provided a chance to take part in co-curricular activities where group cohesiveness and compassion are the major objectives.

- For development of value orientation, participation in the indoor outdoor games, debates and discussions should be encouraged in the institutions.

- In Non Tribal areas parents should give more time to the children at home so that they may not indulge in activities which are not socially plausible.

- The trained teachers should be appointed so that they may understand the individual differences in these institutions. 
IJAMSR 2 (2) www.ijamsr.com CrossRef: https://doi.org/10.31426/ijamsr.2019.2.2.1218

\section{International Journal of Advanced Multidisciplinary Scientific Research (IJAMSR) ISSN:2581-4281}

- Special attention should be given towards the tribal students so as to increase their academic achievements.

- The problem may be taken for further research on greater area and larger sample size so as to generalize the facts more accurately.

\section{Conclusion}

As high school students hail from different socioeconomic and educational backgrounds, they may be given an orientation with regard to the importance of self-motivation through informal addresses, guest lectures, seminars and workshops. Special address and periodical seminars by eminent educationalists and psychologists would yield fruitful results in this regard.

\section{References}

1. A.A.D. Luiz, Tribes of Kerala, Bharatiya SevaSangh, 1962.

2. A.K. Pandey, Tribal Society in India, Manak Publications Pvt.Ltd.New Delhi, 1997.

3. B.K. Roy Burman, "Some Dimensions of Transformation of Tribal Studies in India."-Journal of Social Research, Vol. xxiii, No.3, 1979.
4. Christoph Von Purer, Harnendarf, Tribes of Indiar the Struggle for Survival, M.K. Publications, Rajasthan, 1988.

5. D.D. Nag, Baiga Economy of Madhya Pradesh, M.K. Publications, Calcutta, 1958.

6. GeethaMenon, "Tribal Women : Victims of Development Process", Social Action, October, 1987.

7. JaganathPanday, Tribal Peasantry Dynamics of Development, Inter India Publications, New Delhi, 1981.

8. K.S. Mathur, (ed.), Studies in Social Change, Ethnographic and Folk Culture Society, U.P, 1973.

9. L.C. Mohanthy, An Analysis of the improved Economic Life of Tribals of Orissa and the way towards Integration, Deep and Deep Publishers, 1989.

10. Ministry of Tribal Affairsretrived from http://tribal.nic.in/.aspx on $16^{\text {th }}$ of may 2015.

11. N.N. Yyas, Customs and Traditions of Some Indian Tribes, Vikas Publishing House, New Delhi, 1967.

12. Pradeep Kumar Bose, "Stratification among the Indian Tribes", Kuruhhethra, April 14, 1981.

13. Ramakant, Prasad, A Case Study of Cultural Ecology and Tribal Dynamics, J. KPublishers, AndhraPradesh 1988.

14. Sharma, R.S., Indian Feudalism, MacMillan India Ltd., Delhi, 1980

15. Text of the Constitution (Scheduled Tribes) Order, 1950.

16. Vimal Shah, Tribal Economy in Gujarat, Well Print Publications,

Jaipur, 1969.

17. William, Logan, Malabar Mannual, Vol. I., Madras, 1951 .

18. Yogendra, Singh, Indian Sociology, Vistar Publication, New Delhi, 1986. 